\title{
EMOTIONAL INTELLIGENCE AMONG UNDERGRADUATE NURSING STUDENTS IN SELECTED COLLEGES OF MORANG DISTRICT, NEPAL
}

\author{
Uma Pradhan ${ }^{1^{*}}$, Namu Koirala ${ }^{2}$, Menuka Shrestha ${ }^{2}$, Dharani Dhar Baral ${ }^{3}$, Surya B. Parajuli ${ }^{4}$
}

\section{Affiliation}

1. Lecturer, Department of Psychiatric Nursing, Purbanchal University School of Health Sciences, Nepal

2. Lecturer/Department of Nursing, Purbanchal University School of Health Sciences, Nepal

3. Assistant Professor/School of Public Health and Community Medicine, B. P. Koirala Institute of Health Sciences, Nepal

4. Assistant Professor, Department of Community Medicine, Birat Medical College and Teaching Hospital, Nepal

\section{ARTICLE INFO}

Received : 21 April, 2021

Accepted : 12 December, 2021

Published : 21 February, 2022

(C) Authors retain copyright and grant the journal right of first publication with the work simultaneously licensed under Creative Commons Attribution License CC - BY 4.0 that allows others to share the work with an acknowledgment of the work's authorship and initial publication in this journal.

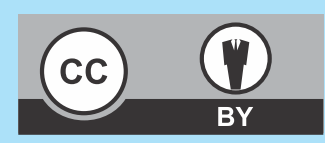

ORA 274

DOI: https://doi.org/10.3126/bjhs.v6i3.43199

* Corresponding Author

Ms. Uma Pradhan

Lecturer

Department of Psychiatric Nursing

Purbanchal University School of Health Sciences, Nepal

Email: umapradhan977@gmail.com

ORCID: https://orcid.org/0000-0002-3703-0794

\section{Citation}

Emotional Intelligence among Undergraduate Nursing Students in Selected Colleges of Morang District, Nepal. Uma Pradhan, Namu Koirala, Menuka Shrestha, Dharani Dhar Baral, Surya B. Parajuli. BJHS 2021;6(3)16. 1590-1594.

\section{ABSTRACT}

Introduction

Emotional Intelligence (EI) is the ability to recognize one's own and other's emotions and capacity to utilize the emotional information to adjust to the environment. Nurse with high EI is found to have a better interpersonal relationship, higher job satisfaction, better leadership abilities, and better academic achievement. There is a gap in information regarding El in nursing students of Morang district.

\section{Objective}

The objective of the study was to find out the emotional intelligence and its association with selected sociodemographic variables among undergraduate nursing students of selected colleges of Morang district, Nepal.

\section{Methodology}

This was a cross-sectional study carried out from June 2020 to November 2020 among 423 undergraduate nursing students from three colleges of Morang district. Ethical clearance was obtained from Purbanchal University School of Health Sciences-Institutional Review Committee (PUSHS-IRC) and informed consent were taken from study participants. A standard tool, "The Schutte Self Report Emotional Intelligence Test (SSEIT)" was used. Data was collected through a google form. Univariate and bivariate analysis was performed. P-value $<0.05$ at $95 \%$ confidence interval was considered statistically significant for bivariate analysis.

\section{Result}

Majority (75.4\%) of nursing students had a high level of EI score and $24.6 \%$ of the students had a moderate level of EI score. There was no statistically significant association of total El score with any of the selected demographic variables. Further, the selected domains such as perception of emotion with an academic year of study $(p=0.02)$, occupation of the mother $(p=0.017)$, management of other's emotions with a year of the study $(p=0.018)$, and utilization of emotion with the type of schooling $(p=0.003)$ were statistically significant.

\section{Conclusion}

Emotional intelligence was high and does not vary with different sociodemographic characteristics among nursing students.

\section{KEYWORDS}

Emotional Intelligence, Nepal, nursing students 


\section{INTRODUCTION}

The nursing profession is a noble profession, where nurses face various emotional turmoil. Managing own emotion and interpreting other's emotion is the most essential prerequisite in this profession. This requires not only critical thinking but also needs integrated emotional intelligence during nursing practice. According to Peter Salovey and John Mayer, "Emotional Intelligence involves the ability to monitor one's own and others' feelings and emotions, to discriminate among them and to use this information to guide one's thinking and actions". ${ }^{1}$ Emotional Intelligence (EI)is also considered as an important factor contributing to academic success. ${ }^{2}$ An emotionally intelligent nurse can work in harmony with his/her thoughts and feelings. Studies have shown that El allows nurses to develop therapeutic relationships to meet patients' and their family's need and work-related conflict-handling styles to better manage stress. ${ }^{4-7}$ Research study shows that nurses' EI has a direct impact on the hospital services quality. ${ }^{8}$ In the nursing profession, El has been associated with good job performance with retention of nurses and positive patient outcomes, ${ }^{9}$ successful managerial styles, ${ }^{10}$ and effective teamwork. ${ }^{11}$ Very little research related to EI has been conducted in Nepal. Identification of El skills among nursing students will help in the effective transition from the academic setting to a professional setting. ${ }^{12}$ Assessing the $\mathrm{EI}$ among nursing students will help to identify the need for the training program and will be a reference to incorporate content of $\mathrm{El}$ in the nursing curriculum. This study will also help to sensitize the participants and authorities to focus on its importance. The present study aims to find out the emotional and its association with selected demographic variables among undergraduate nursing students of selected colleges of Morang district, Nepal.

\section{METHODOLOGY}

The cross-sectional study was undertaken from June 2020 to November 2020 among 423 nursing students enrolled in the BSc Nursing (Bachelor of Science in Nursing)and PBNS (Post Basic Bachelor of Nursing Science) program among three colleges of Morang district. Out of total four colleges of Purbanchal University in Morang district, the three colleges were selected randomly, where Purbanchal University School of Health Sciences (PUSHS) is the constituent college and the Hamro School of Nursing and Koshi Health and Science Campus are the affiliated colleges of Purbanchal University. Ethical clearance of the study was obtained from PUSHS-Institutional Review Committee (Ref no IRC/008/ 2020). As census sampling technique was used in the study, all the nursing students were selected for the study. The total sample size was $(241+103+79)=423$ from PUSHS, Hamro School of Nursing and Koshi Health and Science Campus respectively. Those nursing students who were not willing to participate and did not provide consent were excluded from the study. Four hundred and twenty-three nursing students participated among 492 students. Thus, the response rate was $85.97 \%$.The confidentiality of the students was maintained. A standard tool, "The Schutte Self
Report Emotional Intelligence Test (SSEIT)" was used to collect the data. It is a valid tool with internal consistency (Cronbach's alpha $=0.90$ ) and acceptable test-retest reliability $(0.78) .{ }^{13}$ SSEIT is composed of 33 items and is a five-point Likert scale where $1=$ strongly disagree, 2 = disagree, $3=$ neither disagree nor agree, $4=$ agree, $5=$ strongly agree. All the items were positively scored except for items 5,28 , and 33 . The score ranges from 33 to 165 . The 33 -item was articulated in four subscales: perception of emotions $=10$ items; managing own emotions $=9$ items; managing other's emotions $=8$ items; and utilization of emotions $=6$ items. The level of $\mathrm{EI}$ was categorized as follows: Low El score $\leq 77$, Moderate EI scores 78-121, High El scores $\geq 122$. Data was collected using a self-administered questionnaire which was created in the google form. The students in each academic year were called separately at the online meeting and were given orientation about the tool. Data were analyzed using SPSS version 18. The Chi-square test was used to find the association of El/ El domains with socio-demographic variables. The $p$ value 0.05 or less was considered as significant.

\section{RESULTS}

The findings show that more than half $(59.3 \%)$ of the students were of age group 21-25 years. Sixty-one percent of the students were from the BSc Nursing program and $39 \%$ of students were from the PBNS (Post-Basic Bachelor of Nursing Science) program. Among them, 77.1\% belonged to the single-family, $84.6 \%$ were unmarried, $87 \%$ did their schooling from a private school. Most of the student's parents (38.8\% mother, 33.6\% father) had secondary level education. The majority $(77.3 \%)$ of the student's mother was homemakers, whereas the majority $(36.9 \%)$ of the student's father was a businessman

Table 1: Baseline information of study participants ( $n=423)$

\begin{tabular}{|c|c|c|}
\hline Characteristics & Categories & $n(\%)$ \\
\hline \multirow[t]{4}{*}{ Age (in years) } & $\leq 20$ & $126(29.8)$ \\
\hline & $21-25$ & $251(59.3)$ \\
\hline & $26-30$ & $41(9.7)$ \\
\hline & $>30$ & $5(1.2)$ \\
\hline Mean \pm SD & $22.2 \pm 2.8$ & \\
\hline \multirow[t]{2}{*}{ Program } & BSc Nursing & $258(61.0)$ \\
\hline & PBNS & $165(39.0)$ \\
\hline \multirow[t]{2}{*}{ Type of family } & Joint family & $97(22.9)$ \\
\hline & Single-family & $326(77.1)$ \\
\hline \multirow[t]{2}{*}{ Marital Status } & Married & 65 (15.4) \\
\hline & Unmarried & $358(84.6)$ \\
\hline \multirow[t]{2}{*}{ Schooling } & Government school & $55(13.0)$ \\
\hline & Private school & $368(87.0)$ \\
\hline \multirow{6}{*}{$\begin{array}{l}\text { Mother's } \\
\text { Education }\end{array}$} & Up to Primary & $103(24.3)$ \\
\hline & $\begin{array}{l}\text { Lower Secondary } \\
\text { (class } 6 \text { to } 8 \text { ) }\end{array}$ & $25(5.9)$ \\
\hline & $\begin{array}{l}\text { Secondary } \\
\text { (Class } 9 \text { \&10) }\end{array}$ & $164(38.8)$ \\
\hline & $\begin{array}{l}\text { Higher Secondary } \\
\text { (Class } 11 \text { \& 12) }\end{array}$ & $96(22.7)$ \\
\hline & Up to Bachelor & $30(7.1)$ \\
\hline & Masters and above & $5(1.2)$ \\
\hline
\end{tabular}




\begin{tabular}{|c|c|c|}
\hline Characteristics & Categories & $n(\%)$ \\
\hline \multirow{6}{*}{$\begin{array}{l}\text { Father's } \\
\text { Education }\end{array}$} & Up to Primary & $35(8.3)$ \\
\hline & $\begin{array}{l}\text { Lower Secondary } \\
\text { (class } 6 \text { to } 8 \text { ) }\end{array}$ & $10(2.4)$ \\
\hline & $\begin{array}{l}\text { Secondary } \\
\text { (Class } 9 \& 10 \text { ) }\end{array}$ & $142(33.6)$ \\
\hline & $\begin{array}{l}\text { Higher Secondary } \\
\text { (Class } 11 \text { \& } 12 \text { ) }\end{array}$ & $125(29.6)$ \\
\hline & Bachelor & $82(19.4)$ \\
\hline & Masters and above & $29(6.9)$ \\
\hline \multirow{5}{*}{$\begin{array}{l}\text { Occupation of } \\
\text { Mother }\end{array}$} & Homemaker & $327(77.3)$ \\
\hline & Service & $41(9.7)$ \\
\hline & Business & $36(8.5)$ \\
\hline & Agriculture & $10(2.4)$ \\
\hline & Other & $9(2.1)$ \\
\hline \multirow{8}{*}{$\begin{array}{l}\text { Occupation of } \\
\text { Father }\end{array}$} & Business & $156(36.9)$ \\
\hline & Service & $116(27.4)$ \\
\hline & Agriculture & $69(16.3)$ \\
\hline & Police/Army & $22(5.2)$ \\
\hline & Retired & $12(2.8)$ \\
\hline & Abroad Employee & $16(3.8)$ \\
\hline & Expired & $3(7)$ \\
\hline & Other & 29(6.9) \\
\hline
\end{tabular}

Figure 1 depicts that $26.70 \%$ of the students were from BSc Nursing first year Among PBNS students, $39.40 \%$ of the students were from the third year.

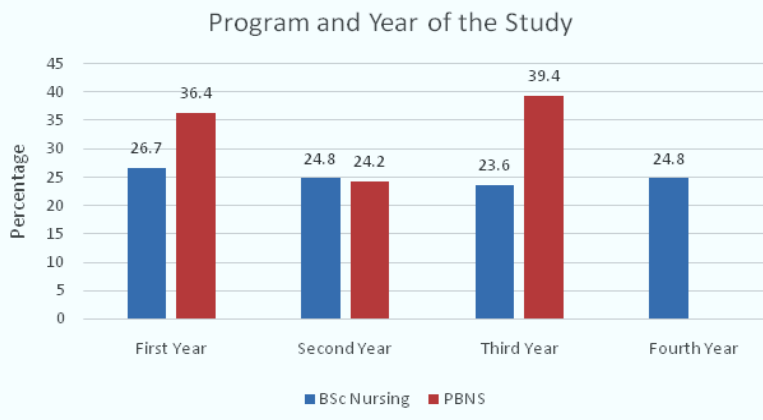

Figure 1: Year-wise distribution of study participants $(n=423)$

Table 2 depicts that $3 / 4^{\text {th }}(75.4 \%)$ of nursing students (BSN and PBNS) had a total High level of El score. Three-fourth (75.6\%) of BSN and $75.2 \%$ of PBNS students scored a high level of El.

Table 2: Level of Emotional Intelligence among study participants $(n=423)$

\begin{tabular}{|l|l|l|l|}
\hline Level of EI & BSN $\boldsymbol{n}(\%)$ & PBNS $\boldsymbol{n}(\%)$ & Total $\boldsymbol{n}(\%)$ \\
\hline Moderate (78-121) & $63(24.4 \%)$ & $41(24.8 \%)$ & $104(24.6)$ \\
\hline High ( $\geq 122)$ & $195(75.6 \%)$ & $124(75.2 \%)$ & $319(75.4)$ \\
\hline
\end{tabular}

Table 3 depicts that the Mean \pm SD of the overall score of El is $128.87 \pm 10.38$. Mean \pm SD of the domains of $\mathrm{EI}$ are $35.64 \pm 4.32,36.90 \pm 3.34,31.61 \pm 2.97,24.72 \pm 2.70$ for Perception of emotions, Management of own emotions,
Management of others' emotions, and Utilization ofemotions respectively.

Table 3: Domains of Emotional Intelligence $(n=423)$
\begin{tabular}{|l|r|}
\hline Types of domain & Mean \pm SD \\
\hline Perception ofemotions & $35.64 \pm 4.32$ \\
\hline Management of ownemotions & $36.90 \pm 3.34$ \\
\hline Management of others'emotions & $31.61 \pm 2.97$ \\
\hline Utilization ofemotions & $24.72 \pm 2.70$ \\
\hline Total & $128.87 \pm 10.38$ \\
\hline
\end{tabular}

Table 4 shows that there was no significant association between the total score of El with selected demographic variables like age, program, year of the study, type of family, marital status, schooling, parent's education, parent's occupation.

\begin{tabular}{|c|c|c|c|c|}
\hline \multirow[t]{2}{*}{ Variables } & \multirow[t]{2}{*}{ Categories } & \multicolumn{2}{|c|}{ Level of EI n (\%) } & \multirow[t]{2}{*}{ P-Value } \\
\hline & & Moderate & High & \\
\hline \multirow[t]{2}{*}{ Age in years } & $\leq 22$ (median) & $66(26.2)$ & $186(73.8)$ & \multirow[t]{2}{*}{0.350} \\
\hline & $>22$ & $38(22.2)$ & $133(77.8)$ & \\
\hline \multirow[t]{2}{*}{ Program } & BScN & $63(24.4)$ & $195(75.6)$ & \multirow[t]{2}{*}{0.920} \\
\hline & PBNS & $41(24.8)$ & $124(75.2)$ & \\
\hline \multirow[t]{2}{*}{ Year of the Study } & First-year & $33(25.6)$ & $96(74.4)$ & \multirow[t]{2}{*}{0.753} \\
\hline & Other years & $71(24.1)$ & $223(75.9)$ & \\
\hline \multirow[t]{2}{*}{ Type of family } & Joint family & 29 (29.9) & $68(70.1)$ & \multirow[t]{2}{*}{0.166} \\
\hline & Single-family & $75(23.0)$ & $251(77.0)$ & \\
\hline \multirow[t]{2}{*}{ Marital Status } & Married & $12(18.5)$ & $53(81.5)$ & \multirow[t]{2}{*}{0.213} \\
\hline & Unmarried & $92(25.7)$ & $266(74.3)$ & \\
\hline \multirow[t]{2}{*}{ Schooling } & $\begin{array}{l}\text { Government } \\
\text { school }\end{array}$ & $12(21.8)$ & $43(78.2)$ & \multirow[t]{2}{*}{0.609} \\
\hline & Private school & $92(25.0)$ & $276(75.0)$ & \\
\hline \multirow{2}{*}{$\begin{array}{l}\text { Mother's } \\
\text { Education }\end{array}$} & $\begin{array}{l}\text { Up to Higher } \\
\text { Secondary }\end{array}$ & $70(24.0)$ & $222(76.0)$ & \multirow[t]{2}{*}{0.662} \\
\hline & $\begin{array}{l}\text { Bachelor and } \\
\text { above }\end{array}$ & $34(26.0)$ & $97(74.0)$ & \\
\hline \multirow{2}{*}{$\begin{array}{l}\text { Father's } \\
\text { Education }\end{array}$} & $\begin{array}{l}\text { Up to Higher } \\
\text { Secondary }\end{array}$ & $75(24.0)$ & $237(76.0)$ & \multirow[t]{2}{*}{0.661} \\
\hline & $\begin{array}{l}\text { Bachelor and } \\
\text { above }\end{array}$ & $29(26.1)$ & $82(73.9)$ & \\
\hline \multirow{2}{*}{$\begin{array}{l}\text { Mother's } \\
\text { Occupation }\end{array}$} & Home Maker & $85(26.0)$ & $242(74.0)$ & \multirow[t]{2}{*}{0.215} \\
\hline & Others & $19(19.8)$ & $77(80.2)$ & \\
\hline \multirow{2}{*}{$\begin{array}{l}\text { Father's } \\
\text { Occupation }\end{array}$} & Business & $42(26.9)$ & $114(73.1)$ & \multirow[t]{2}{*}{0.394} \\
\hline & Others & $62(23.2)$ & 205 (76.8) & \\
\hline
\end{tabular}

Findings in Table 5 depict that the Present study showed that there was a significant association of El domain: perception of emotion with an academic year of the study $(p=0.020)$ and occupation of the mother $(p=0.017)$. The study also revealed that management of other's emotions was significantly associated with the year of the study $(p=0.018)$ and utilization of the emotion was associated with the type of schooling $(p=0.003)$. 
Table 5: Association of El Domains with Selected Demographic Variables $(n=423)$

\begin{tabular}{|c|c|c|c|c|c|}
\hline \multirow[t]{2}{*}{ Variables } & \multirow[t]{2}{*}{ Categories } & \multicolumn{2}{|c|}{$\begin{array}{c}\text { Perception of } \\
\text { emotions } n(\%)\end{array}$} & \multicolumn{2}{|c|}{$\begin{array}{l}\text { Management of own } \\
\text { emotions } n(\%)\end{array}$} \\
\hline & & Moderate & High & Moderate & High \\
\hline \multirow[t]{2}{*}{ Age in years } & $\leq 22$ & $151(59.9)$ & $101(40.1)$ & $19(7.5)$ & $233(92.5)$ \\
\hline & $>22$ & $92(53.8)$ & $79(46.2)$ & $11(6.4)$ & $160(93.6)$ \\
\hline \multicolumn{2}{|l|}{ P-Value } & & 0.212 & & 0.663 \\
\hline \multirow[t]{2}{*}{ Program } & BSc Nursing & $149(57.8)$ & $109(42.2)$ & $16(6.2)$ & $242(93.8)$ \\
\hline & PBNS & 94 (57) & $71(43.0)$ & $14(8.5)$ & $151(91.5)$ \\
\hline \multicolumn{2}{|l|}{ P-Value } & & 0.874 & & 0.372 \\
\hline \multirow[t]{2}{*}{ Year of the Study } & First year & $85(65.9)$ & $44(34.1)$ & $10(7.8)$ & $119(92.2)$ \\
\hline & Other years & $158(53.7)$ & $136(46.3)$ & $20(6.8)$ & $274(93.2)$ \\
\hline \multicolumn{2}{|l|}{ P-Value } & & $0.020 *$ & & 0.726 \\
\hline \multirow[t]{2}{*}{ Type of family } & Joint & $55(57.7)$ & $41(42.3)$ & $9(9.3)$ & $88(90.7)$ \\
\hline & Single & $187(57.4)$ & $139(42.6)$ & $21(6.4)$ & $305(93.6)$ \\
\hline \multicolumn{2}{|l|}{ P-Value } & & 0.984 & & 0.339 \\
\hline \multirow[t]{2}{*}{ Marital Status } & Married & $35(53.8)$ & $30(46.2)$ & $5(7.7)$ & $60(92.3)$ \\
\hline & Unmarried & $208(58.1)$ & $150(41.9)$ & $25(7.0)$ & $333(93.0)$ \\
\hline \multicolumn{2}{|l|}{ P-Value } & & 0.523 & & $0.795 \#$ \\
\hline \multirow[t]{2}{*}{ Studied in } & Government school & $26(47.3)$ & $29(52.7)$ & $4(7.3)$ & $51(92.7)$ \\
\hline & Private school & $217(59.0)$ & $151(41.0)$ & $26(7.1)$ & 342 (92.9) \\
\hline \multicolumn{2}{|l|}{ P-Value } & 0.102 & & $1.000 \#$ & \\
\hline \multirow[t]{2}{*}{$\begin{array}{l}\text { Mother's } \\
\text { Education }\end{array}$} & $\begin{array}{l}\text { Up to Higher } \\
\text { Secondary }\end{array}$ & $164(56.2)$ & $128(43.8)$ & $21(7.2)$ & $271(92.8)$ \\
\hline & Bachelor and above & $79(60.3)$ & $52(39.7)$ & $9(6.9)$ & $122(93.1)$ \\
\hline \multicolumn{2}{|l|}{ P-Value } & 0.426 & & 0.905 & \\
\hline \multirow[t]{2}{*}{$\begin{array}{l}\text { Father's } \\
\text { Education }\end{array}$} & $\begin{array}{l}\text { Up to Higher } \\
\text { Secondary }\end{array}$ & $176(56.4)$ & $136(43.6)$ & $21(6.7)$ & $291(93.3)$ \\
\hline & Bachelor and above & $67(60.4)$ & $44(39.6)$ & $9(8.1)$ & 102 (91.9) \\
\hline \multicolumn{2}{|l|}{ P-Value } & 0.470 & & 0.627 & \\
\hline \multirow{2}{*}{$\begin{array}{l}\text { Mother's } \\
\text { Occupation }\end{array}$} & Home Maker & $198(60.6)$ & $129(39.4)$ & $26(8.0)$ & $301(92.0)$ \\
\hline & Others & 45 (46.9) & $51(53.1)$ & $4(4.2)$ & $92(95.8)$ \\
\hline
\end{tabular}

\section{DISCUSSION}

The present study findings show that $75.4 \%$ of nursing students had a total high level of Emotional Intelligence score. The study was similar to the findings of a study conducted among Saudi nursing students ${ }^{14}$ as none of the nursing students had a low level of emotional intelligence. Other studies done in Nigeria by Omoronyia FRet al ${ }^{15}$ was also consistent with the findings of the present study. Intermediate level of El was found in the majority of the samples in a study done by Sinha Bet al $^{16}$ in Nepal, HassaliM et $\mathrm{al}^{17}$ in Malaysia, Kaya $\mathrm{H}^{18}$ in Turkey, Mahmoud $\mathrm{HM}^{19}$ et al in Egypt, Codier E et al $^{2}$ in the United States.

Present study findings show comparatively higher El than the studies conducted among nursing students of Riyadh and Tanta by Moawed $S$ et al. $^{2}$ The dissimilarities in the findings may be related to the age differences between the studies. The mean age of the students in the present study being higher than the compared study group.

The present study also showed contradictory findings on a study conducted by Faye A et $\mathrm{al}^{20}$ in India where $70 \%$ of the post-graduate medical students had low El scores. The differences in the findings might be because of the increased workload of the postgraduate medical students.

The mean \pm SD of the overall score of $\mathrm{El}$ is $128.87 \pm 10.38$. Mean \pm SD of the domains of El are $35.64 \pm 4.32,36.90 \pm 3.34$, $31.61 \pm 2.97,24.72 \pm 2.70$ for Perception of emotions, Management of own emotions, Management of others' emotions, and Utilization of emotions respectively. The finding of the study is in line with the study conducted by Ravikumar $\mathrm{R}$ et $\mathrm{al}^{21}$ among post-graduate medical students in New Delhi, India.

The present study shows that there was no significant association ( $p>0.05$ ) between the El score with the selected demographic variables which was similar to the findings of a study among Turkish clinical nurses conducted by Kahraman $\mathrm{N}$ et al. ${ }^{22} \mathrm{~A}$ study done in Nepal by Sinha $\mathrm{B}$ et $\mathrm{al}^{16}$ is also consistent with the findings in which no significant association was found with age, type of family, parent's educational status, and program. Another study conducted in Government college of Eastern Nepal is consistent with the findings of present study. ${ }^{23} A$ similar finding was present in the longitudinal study done by Kaya et al $^{18}$ in Turkey and Mahmoud HM et al $^{19}$ in Egypt where no significant differences in El score with the academic year/ semester. In contrary to the present finding, a study done by Faye et $\mathrm{al}^{20}$ and Azimi $S$ et al $^{24}$ in India found that $\mathrm{El}$ increases among married students. The differences in findings may be because both males and females are included in the later studies.

The present study showed that there was a significant association of El domain: perception of emotion with an academic year of the study and occupation of the mother. The study also revealed that management of other's emotions was significantly associated with the year of the study and utilization of the emotion was associated with the type of schooling. Findings were similar to the study done by postgraduate medical students in New Delhi, where students who studied in a government school was a more emotionally intelligent and academic year has significant differences in sub-dimensions of EI $(p=0.018) .^{21}$ The differences in El domains in the academic year might be because students in other academic years might get emotional maturity because of more exposure to clinical and community setting in comparison to first-year students.

\section{CONCLUSION}

Emotional intelligence was high and does not vary with different socio demographic characteristics among nursing students.

\section{RECOMMENDATION}

We recommend consideration of all socio demographic characteristics for good emotional intelligence of nursing students. We can suggest a phenomenological study for a depth understanding of emotional intelligence.

\section{LIMITATION OF THE STUDY}

We were not able to confirm ruling out social desirability bias among study participants. 


\section{ACKNOWLEDGMENT}

We would like to acknowledge the Institutional Review Committee of PUSHS-IRC.We are very much thankful to nursing students for their participation and immense contribution. We would like to thank the Purbanchal University, Office of Dean for providing a faculty grant to conduct this research.

\section{FINANCIAL DISCLOSURE}

The research was funded by Purbanchal University, Office of Dean, Faculty of Medical and Allied Sciences.

\section{CONFLICT OF INTEREST}

We declare no conflict of interest.

\section{REFERENCES}

1. Salovey P, Mayer JD. Emotional Intelligence.Imagination, Cognition and Personality. 1990;9(3):185-211. DOI:10.2190/DUGG-P24E52WK-6CDG

2. Codier $\mathrm{E}$, Odell $\mathrm{E}$. Measured emotional intelligence ability and grade point average in nursing students. Nurse Educ Today. 2014;34(4) :608-12. DOI:10.1016/j.nedt.2013.06.007

3. Freshwater $D$, Stickley $T$. The heart of the art: emotional intelligence in nurse education. Nursing inquiry. 2004;11(2):91-8. DOI:10.1111/j. 1440-1800.2004.00198.x

4. Cadman C, Brewer J. Emotional intelligence: a vital prerequisite for recruitment in nursing. Journal of nursing management. 2001;9(6) :321-4. DOI:10.1046/j.0966-0429.2001.00261.x

5. Sim S, Bang M. Emotional Intelligence, Stress Coping, and Adjustment to College Life in Nursing Students. International Journal of Bio-Science and Bio-Technology. 2016;8:21-32. DOI: 10.14257/ ijbsbt.2016.8.3.03

6. Gerits L, Derksen JJ, Verbruggen AB. Emotional intelligence and adaptive success of nurses caring for people with mental retardation and severe behavior problems. Mental retardation. 2004;42(2):10621. DOI: $10.1352 / 0047-6765(2004) 42<106$ :eiaaso>2.0.co;2

7. Morrison J. The relationship between emotional intelligence competencies and preferred conflict-handling styles.Journal of nursing management. 2008;16(8):974-83.DOI:10.1111/j.13652834.2008.00876.x

8. RanjbarEzzatabadi M, Bahrami MA, Hadizadeh F, Arab M, Nasiri S, Amiresmaili $M$, et al. Nurses' emotional intelligence impact on the quality of hospital services. Iranian Red Crescent medical journal. 2012;14(12):758-63. DOI: 10.5812/ircmj.926

9. Kooker BM, Shoultz J, Codier EE. Identifying emotional intelligence in professional nursing practice. Journal of professional nursing: official journal of the American Association of Colleges of Nursing. 2007;23(1):30-6. DOI: 10.1016/j.profnurs.2006.12.004

10. Horton-Deutsch S, Sherwood G. Reflection: an educational strategy to develop emotionally competent nurse leaders. Journal of nursing management. 2008;16(8):946-54.DOI:10.1111/j.1365-2834.2008.00957.x

11. McCallin A, Bamford A. Interdisciplinary teamwork: is the influence of emotional intelligence fully appreciated? Journal of nursing management. 2007;15(4):386-91. DOI:10.1111/j.1365-2834.2007. 00711.x

12. Kramer M, Halfer D, Maguire P, Schmalenberg C. Impact of healthy work environments and multistage nurse residency programs on retention of newly licensed RNs. The Journal of nursing administration. 2012;42(3):148-59. DOI:10.1097/NNA. 0b013e 31824808e3

13. Schutte NS, Malouff JM, Hall LE, Haggerty DJ, Cooper JT, Golden CJ, et al. Development and validation of a measure of emotional intelligence. Personality and Individual Differences. 1998;25(2):16777. DOI:10.1016/S0191-8869(98)00001-4
14. EbtsamAlyAbouHashish EFB. Emotional Intelligence among Saudi Nursing Students and Its Relationship to Their Critical Thinking Disposition at College of Nursing- Jeddah, Saudi Arabia.American Journal of Nursing Research. 2018;6(6):350-8. DOI:10.12691/ajnr-6-6-2

15. Faith R. Omoronyia LEOEIO. Psychiatric Nurses' Level of Emotional Intelligence in a Developing Country: A Survey in Neuropsychiatric Hospitals in The Niger-Delta Region, Nigeria. EAS Journal of Nursing and Midwifery. 2020;2(3):9. DOI:10.36349/EASJNM.2020.v02i03.001

16. Sinha B, Bajracharya R, Pandey S, KC S, Koirala S, Kushwaha MP. Emotional Intelligence among undergraduate nursing students. International Journal of Scientific and Research Publications. 2017;7(12):622-9. DOI:10.13140/RG.2.2.14224.92165

17. Hassali M, Hussain R, Saleem F, Iqbal Q, Mohammad A, Ahmad A, et al. Perceived Emotional Intelligence and Its Association with the Demographic Characteristics among Pharmacy Students: A CrossSectional Study. Journal of Pharmacy Practice and Community Medicine. 2017;2017:108-13. DOI:10.5530/jppcm.2017.3.25

18. Kaya $H$, Şenyuva $E$, Bodur $G$. Developing critical thinking disposition and emotional intelligence of nursing students: longitudinal research. Nurse Education Today. 2017;48:72-7. DOI:10.1016/j. nedt. 2016.09.011

19. Hayam Mansour Mahmoud SMAE-D, MarwaAbd El-Gawad Ahmed Mousa. Emotional Intelligence among Baccalaureate Students at the Faculty of Nursing, Alexandria University, Egypt: A Cross-sectional Study. Journal of Education and Practice. 2013;4(7):49-61.Corpus ID: 56159828

20. Faye A, Kalra G, Swamy R, Shukla A, Subramanyam A, Kamath R. Study of emotional intelligence and empathy in medical postgraduates. Indian journal of psychiatry. 2011;53:140-4. DOI: 10.4103/00195545.82541

21. Ravikumar R, Rajoura OP, Sharma R, Bhatia MS. A Study of Emotional Intelligence Among Postgraduate Medical Students in Delhi. Cureus. 2017;9(1):e989-e. DOI:10.7759/cureus.989

22. NilgunKahraman DH. Identifying emotional intelligence skills of Turkish clinical nurses according to sociodemographic and professional variables.Journal of Clinical Nursing. 2016(25):1006-15. DOI:10.1111/jocn.13122

23. Shrestha M, Mandal PK. Emotional intelligence among nursing students of a government campus in eastern Nepal. Journal of Kathmandu Medical College. 2021;10(1):39-42.

24. Azimi S, Farid AAA, Fard MJK, Khoei N. Emotional intelligence of dental students and patient satisfaction. European Journal of Dental Education. 2010;14(3):129-32. DOI:10.1111/j.16000579.2009.00596.x 